\title{
Online computer science workshops for educators in higher education during Covid-19: challenges and opportunities of a forced distance learning
}

\author{
Elena Pacetti ${ }^{\mathrm{a}}$, Alessandro Soriani ${ }^{\mathrm{b}}$ \\ ${ }^{a}$ University of Bologna, Italy, elena.pacetti@ unibo.it, https://orcid.org/0000-0003-0204-2215 \\ ${ }^{b}$ University of Bologna, Italy, alessandro.soriani@ unibo.it, https://orcid.org/0000-0001-7152-6112
}

\begin{abstract}
This study focuses on a course belonging to the University of Bologna's bachelor's degrees 'Expert in Social and Cultural Education' and 'Educator in Childhood Social Services' called 'Computer Science Lab-based course', which aims to develop digital competences necessary for the educational profession. Before COVID-19, this face-to-face compulsory workshop-based course consisted of nine parallel teachings with different programmes and teachers. Due to the impossibility of providing regular lessons, teachers have been forced to revise their working methods by using different distance learning strategies. This paper aims to offer an understanding of the situation by analysing teachers' and students' perceptions collected through questionnaires in relation to the following aspects: most used and effective teaching strategies; technical, communicative and relational difficulties encountered by teachers and students; aspects related to distance learning methods and perception of the usefulness of the course for the educational profession.
\end{abstract}

Keywords: distance learning; educator; higher education; workshop.

\section{The professionalism of socio-pedagogical educators}

\subsection{A competence-based approach}

The figure of the socio-pedagogical educator in the Italian context is characterised by complexity and liquidity (Iori, 2018): a profession formed by the Bachelor degree in Educational Sciences (class L-19), able to design and implement educational interventions in many different areas (school, community, day care centres, play libraries, museums, educational institutions) for people of all ages (from early childhood to the elderly) and with socio-educational, educational and pedagogical functions. The training for this profession provides 'interdisciplinary knowledge and competences that help to understand in its complexity the educational, formal and informal happening, and to act in it' (Oggionni \& Palmieri, 2019, p. 210).

The theme of competences is closely related to the challenges and difficulties of educational systems, in this case at the academic level, and to how formal education has changed and continues to change in an increasingly unstable and flexible labour market and valuing learning as a life-long process. Without pretensions to address the topic in a comprehensive way, the model of education has in the past decades moved from a knowledge and skills-centred curriculum to one centred on competences. The international debate underlines the need to train competent students who are able to integrate knowledge, motivation, values, emotions, ethics and social behaviour in order to act and solve problems (Rychen \& Salganik, 2003). The European Union also stresses the need for a reorganisation of knowledge to adapt to the interdisciplinary character of a changing and complex society (European Commission, 2003). A competence-based approach allows students to put their knowledge into practice in a way that highlights a professional approach to their work, competences that are usually demonstrated through the elaboration and support of topics and 


\section{Online computer science workshops for educators in higher education during Covid-19: challenges and opportunities of a forced distance learning \\ Pacetti, Soriani}

problem-solving in their field of study (Joint Quality Initiative informal group, 2002). Also, at the European level, the Bologna Process ${ }^{1}$, which in 1999 was created to harmonise European education systems at the university level and to allow more easily the mobility and exchange of teachers and students, promotes the use of tools for qualification and comparison of university curricula, such as Dublin ${ }^{2}$ descriptors that formalise learning outcomes according to five areas, namely, applying knowledge and understanding, making judgements, communication skills and learning skills. In this context, there are several study and research actions to support an education system that identifies competences and learning outcomes.

In the international field, the research group that refers to the Tuning Academy has developed a methodology to design training paths focused on competences (generic and specific) and learning outcomes, involving universities (teachers, students, administrative staff and graduates) to define strategies and implement new curricula. In the Italian context, the Teco Project (promoted by ANVUR) aims to build the set of indicators related to the transversal and disciplinary competences of specific courses of study activated in Italy, starting from the analysis of the Single Annual Cards (SUA) of the courses themselves to evaluating the learning outcomes of university students.

In this context, it is clear that the professionalism of the L-19 class educator, due to its complexity and it being a professional working in many areas, is built with a systemic approach that allows the interrelation between different disciplines, between different competences and using active teaching methodologies. In particular, 'The internship and the workshop allow the training in the field, ensuring the transition from knowledge to knowledge doing, emphasizing doing rather than saying' (Rosati \& De Santis, 2020, p. 127). The workshop promotes experiences of simulation of practical situations where, in this way, students can analyse, experiment, critically evaluate pedagogical and didactic knowledge (both general and disciplinary) acquired, co-constructing competences within a group. The workshops represent a formative approach focused on active experiential learning (learning by doing) that allow students to build knowledge through experience, broaden the variety of approaches with which to tackle a task, learn in real and meaningful contexts, adopt individualised learning approaches, situate learning in the relational network and social experience, use multiple forms of knowledge representation and encourage awareness of how the process of knowledge construction takes place (Honebein, 1996).

Competence-based learning (also in the university environment) requires, therefore, active teaching methodologies that allow the active participation of all students. Confronting students with problems (realistic and complex, and not only 'exercises'), problematic situations on an area of knowledge or personal experience that is at least partly familiar to students causes a cognitive conflict with the students' preliminary knowledge and opens to different and not predetermined hypotheses and cognitive paths. Learning to co-construct knowledge in a collaborative context such as that of a university laboratory is not only more effective for individual competences, but also important to develop transversal competences (teamwork, mediation, negotiation, tolerance, empathy, etc.), essential factors in the labour market (Pacetti, 2017).

The courses of study for socio-pedagogical educators of class L-19 include in their teaching plan a 'Computer science lab-based course' ${ }^{3}$ that, integrated with the learning fundamental to the educator's profile, could help to acquire not only (or not so much) computer skills, but also digital competences in support of a professionalism that daily faces the challenges of the knowledge society, with the opportunities of media education, technologies for education and digital citizenship, themes that, in fact, also find space in different teachings of the course of study and that represent one of the priorities for the future of universities in Europe (Whittle \& Rampton, 2020). The 'Computer science labbased course', together with the teachings related to it, take on different connotations in the 50 three-year degrees activated in Italy for the academic year 2020/2021 . A recent analysis has shown that in most of the L-19 courses, these issues do not emerge sufficiently in the competences, objectives and expected learning outcomes (Rossi, 2019).

This essay aims to offer an alternative point of view on the importance of digital competences for socio-pedagogical educators and how the Covid-19 emergency and the consequent use of distance learning in university, has allowed students to become more aware of their professional role and work contexts, contexts that increasingly need professionals able to reflect critically on the complexity of our lives.

\footnotetext{
${ }^{1}$ For a more in-depth analysis of the Bologna Process, see the EHEA website, European Higher Education Area, at http://www.ehea.info/index.php

${ }^{2}$ More information at http://ecahe.eu/w/index.php/Dublin Descriptors

${ }^{3}$ An important note must be done about the name of the course: the official translation that can be found in the University of Bologna's website is 'Computer science lab based course' (https://www.unibo.it/en/teaching/course-unit-catalogue/course-unit/2020/436253). The name could raise some misunderstandings as it is a short course (three ECTS for 24 contact hours) that usually is run in IT laboratories equipped with PCs at students' disposal. In fact, the course can be considered as a workshop-based course due to the kinds of educational methodologies adopted and a competencebased approach followed in the planning of the programmes. The course is mandatory in term of presence and therefore, to ensure the fact that every student could attend, the Department of Education Studies of the University of Bologna implemented a series of different iterations of the same course (18 for the academic year 2019/2020, managed by 10 different teachers). From now on, in the text, we will refer to the 'Computer science lab based courses' as 'workshops'.

${ }^{4}$ The counting was made in the framework of a research that can be consulted at https://www.universitaly.it/
} 


\section{Online computer science workshops for educators in higher education during Covid-19: challenges and opportunities of a forced distance learning \\ Pacetti, Soriani}

\subsection{The European DigComp framework for Educators}

Before moving on to the research's description, we should point out that the common ground upon which all the different workshops have been built is represented by the European framework DIGCOMPEDU (Redecker \& Punie, 2017). The choice was motivated by two main elements: the need for working with a competence-based approach and the need for aligning the different programmes of the workshops so that they could be coherent in terms of learning outcomes. The DIGCOMPEDU framework provided the perfect tools for planning, running and evaluating the different proposals in a consistent and coherent way.

The European Union, through the work of the Joint Research Centre - The Institute for Prospective Technological Studies (JRC), has promoted the implementation of the DIGCOMP framework (Ferrari, 2013), acting as a reference point in the definition of a formalised system of competences, related to technologies, necessary for European citizens for employment, personal and professional growth and social inclusion. In its most recent version, DIGCOMP 2.1 (Carrettero Gomez, Vuorikari, \& Punie, 2017), the framework in its version 2.0 (Vuorikari, Punie, Carrettero Gomez, \& Van Den Brande, 2016) has undergone some changes, coming to include a system of 21 competences - articulated according to eight levels of mastery - grouped in five competence areas: Information and Data Literacy, Communication and Collaboration, Creation of digital contents, Security, Problem-Solving.

The model is strongly centred on providing basic guidance on how to use technology effectively, critically, collaboratively, creatively and safely. This focus on technological and cognitive aspects is undoubtedly useful and necessary, but results, according to some points of view, in a competence system lacking in ethical-social aspects (Calvani, Fini, \& Ranieri, 2010).

The DIGCOMP framework has been further extended and enriched with a new competence system specifically designed to define a European framework of digital competences for educators, teachers and trainers: the Proposal for a European Framework for the Digital Competence of Educators.

The model presents 22 competences divided into six different areas, which in turn are divided into three macrocategories. Like DIGCOMP 2.1, also in this framework, for each of the 22 competences, levels of mastery are specified (structured in the model of the level of linguistic competence in Figure 1) which are listed here from the most basic to the most advanced: newcomer (A1), explorer (A2), integrator (B1), expert (B2), leader (C1), pioneer (C2).

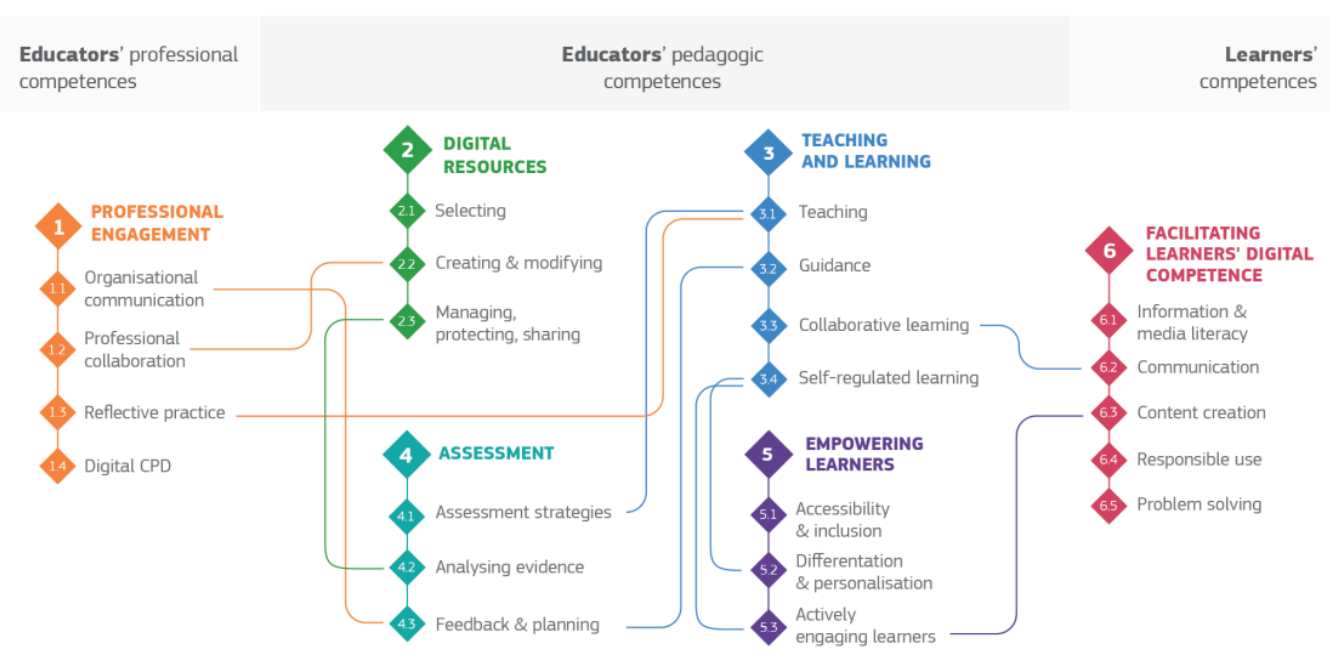

Fig. 1. The DIGCOMPEDU framework.

This division into three areas - educators' professional competences, educators' pedagogical competences, learners' digital competences - is particularly significant because it emphasises that, in order to educate young citizens to technologies, it is not simply necessary to possess basic digital competences, but it is appropriate to build and maintain a professional profile capable of the following:

1. organisational, collaborative, reflective qualities with respect to their own professional practices;

2. being aware of the digital resources to offer their students;

3. teaching and pedagogical qualities supported not simply by common sense and enthusiasm, but by a rigorous and careful method;

4. evaluating effectively and self-critically the effectiveness or weaknesses of their own practices;

5. building learning contexts (digital and non-digital) that are engaging, responsive to learners' needs, equitable and inclusive. 


\section{Online computer science workshops for educators in higher education during Covid-19: challenges and opportunities of a forced distance learning \\ Pacetti, Soriani}

\subsection{Distance learning education: a response to an emergency}

The debate about distance learning education in the field of higher education is a trend since more than 30 years, especially if we consider the wide possible activities going under this term (e.g. online learning, online teaching, technology-based/enhanced learning, e-learning, blended learning, open learning, open education, to cite some of them) and the relative tools such as Open Educational Resources (OER) or Massive Open Online Course (MOOC). Research underlines the importance of planning and designing courses following variables such as class size, role of teacher, students and assessment, pedagogy model, typology of communication and feedback for an effective learning (Means, Bakia, \& Murphy, 2014). Despite the well-documented experimentations, in Italian universities, distance learning is a still a 'niche trend' (Perla et al., 2020); but COVID-19 pandemic created an unexpected situation and development in all school systems, giving universities an extraordinary impulse to get involved in the search for strategy to face the current crisis and guarantee continuity in teaching.

Distance education in Italian universities has been an emergency and immediate answer to this new situation: students and teachers are forced to transfer and adapt their teaching and learning methodologies to new learning environments. After one or more weeks from the lockdown, Italian higher education institutions were able to transpose most of their didactic activities online, using platforms (Microsoft Teams, Zoom, Google Meet) to communicate, exchange materials, assess and graduate students. Several researches (Luppi et al., 2020; Di Palma \& Belfiore, 2020; Giovannella, 2020; Bruschi, 2020) could collect data from the majority of Italian universities, providing evidence for opportunities, weaknesses, strengths and difficulties of distance education that these institutions were affording during the academic year 2019/2020. More correctly, it would be appropriate to consider that teachers and students were working in a situation of 'emergency remote teaching' (ERT), stressing the fact that, especially in the initial phase of implementation, there was not enough time to design and plan adequate activities, to select the opportune tools, to check the connection and availability of digital tools for students, and going online was the only alternative to suspend any educational activity (Hodges et al., 2020). However, in this article, the authors preferred to keep the term distance learning education, translating the Italian term 'didattica a distanza' and in agreement with the relevant scientific literature (Williamson, Eynon, \& Potter, 2020; Harrison, 2020; Riedling, 2020).

\section{The research}

\subsection{The context}

The present research was started before the COVID-19 pandemic that spread worldwide during the academic year 2019/2020. The original scope of the inquiry was to measure the quality of the workshops' proposals and to understand which kinds of competences were the most developed. The goal was to get a phenomenology of the students' digital competences and to know about the challenges faced and the best aspects of different workshops. With the new situation - based completely on distance learning during the second semester - the researchers chose to focus also on the perceptions of teachers and students about distance learning processes, on the quality of the proposals and on the differences and the positive elements that connoted the different workshops.

During the academic year 2019/2020, within the two bachelor's degrees in Expert in Social and Cultural Education (SCE) and Educator in Childhood Social Services (CSS) held at the Department of Education Studies of the University of Bologna, 18 Computer Science workshops were held by 12 teachers: 8 during the first semester (which were held in attendance) and 10 in the second semester (which were held remotely).

The workshops of the first semester were held with students present in a classroom equipped with 32 PC workstations and Internet connection. In the second semester, following the spread of the Coronavirus pandemic, the teachers had to carry out lessons online using the official Microsoft Teams platform. Among the nine lecturers who conducted their courses in the second semester, only one was able to carry out part of his work (the first lesson) before the lockdown.

As mentioned before, each teacher could propose a different programme, and hereby are listed the main topics of each workshop (Table 1):

Table 1. 'Computer Science Lab-based courses' main topics

\begin{tabular}{l|l}
\hline First semester (FS) & Second semester (SS) \\
\hline Introduction to coding for early childhood services' educators & Pedagogical implications of video games \\
Introduction to coding for extra school educators & Serious games and video games in educational contexts
\end{tabular}




\section{Online computer science workshops for educators in higher education during Covid-19: challenges and opportunities of a forced distance learning \\ Pacetti, Soriani}

Online tools for planning educational activities

Introduction to online collaborative tools for extra school educational contexts

Introduction to online collaborative tools for extra school educational contexts

Documentation with digital tools for early childhood services' educators

Documentation with digital tools for extra school educators

General foundations of IT and educators' digital competences
Digital tools to produce music for educational purposes

Digital tools to produce music for educational purposes

Introduction to coding for early childhood services' educators

Introduction to coding for extra school educators

General foundations of IT and educators' digital competences

General foundations of IT and educators' digital competences

Documentation with digital tools for early childhood services' educators

Documentation with digital tools for extra school educators

Although the programmes of the workshops were different in terms of topics and in terms of the digital tools presented, every course was conceived following a competence-based approach, meaning that not only the educational activities were crafted to develop knowledges, skills and attitudes, but also every learning outcome had to be planned and expressed according to the aforementioned DIGCOMPEDU framework.

In order to refer to the workshops in a more rigorous way, during the course of the contribution, a nomenclature will be used to help the reader to distinguish the degree course, the semester and the teacher responsible. By way of example, the code SCE-1D refers to the laboratory of the teacher D held in the first semester within the degree in Expert in SCE; the code CSS-2IR, on the other hand, refers to the laboratory of the teacher I, held in the second semester within the degree in Educator in CSS. The additional R indicates that the teaching was replicated with a second class.

FS stands for 'first semester', while SS stands for 'second semester'.

\subsection{Research's aim and questions}

The aim of the research is to introduce a reflection on online workshop university training designed for professionals in the field of education (social and cultural educators and childcare services). During the lockdown period caused by the COVID-19 emergency, the workshops for the second semester were conducted entirely online; thus, the following questions are posed as a critical reflection regarding the experience just ended:

- What are the perceptions of teachers and students regarding distance learning?

- What differences, in terms of the quality of the proposal, and what difficulties and/or positive elements have been encountered by teachers and students between the workshops' proposals of the first and second semesters?

- How can we build an effective, inclusive and sustainable laboratory proposal regarding information technology for educational professionals?

\subsection{Data collection tools}

To collect data from both teachers and students in the first and second semesters, four types of questionnaires were distributed:

1. Questionnaire to the teachers of the first semester's workshops. The tool, containing closed and open questions, was designed to be completed in about 30-40 minutes and was divided into four sections:

- general information about the workshop (lecturer, degree course, location, laboratory title);

- workshop programme (number of hours, learning objectives, proposed digital instruments, working methods and skills developed);

- modalities of evaluation and

- considerations on effectiveness and the problems encountered.

2. Questionnaire to the teachers of the second semester's workshops. The questionnaire proposed to the teachers of the second semester was entirely consistent with the one previously distributed, but contained an additional section aimed at capturing the teachers' perceptions of the positive elements and the difficulties encountered with respect to the method of working at a distance. Both questionnaires addressed to teachers were distributed by e-mail through a spreadsheet.

3. Questionnaire (outgoing) to students in the first semester. The questionnaire, designed to be completed in $15-20$ minutes, was distributed to students through an online form at the end of the lessons. It contained open and closed questions, collected in the following sections: 


\section{Online computer science workshops for educators in higher education during Covid-19: challenges and opportunities of a forced distance learning \\ Pacetti, Soriani}

- personal details (student's gender, age, degree course, location, teacher with whom the workshop was held, reason for choosing that programme) and

- evaluation of the workshop (effectiveness of the teacher's teaching strategies, satisfaction with the programme, perceived utility for the profession, positive aspects and critical issues that emerged).

4. Questionnaire (outgoing) to students of the second semester: the same questionnaire of the first semester enriched with specific questions about distance learning. The questionnaire designed to be completed in 15-20 minutes was distributed to students through an online form at the end of the lessons and contained open and closed questions to collect students' opinions on the quality of the workshop and on the aspects related to distance learning.

\subsection{Research population}

The 12 teachers who designed and carried out the 18 workshops proposed to students and a total of students divided between the first and second semesters (including incoming and outgoing respondents) participated in the research, which is described in Table 2.

Table 2. Questionnaires collected during the first and second semesters

\begin{tabular}{|c|c|c|c|c|}
\hline First semester & Students' answers & Second semester & $\begin{array}{l}\text { Students' answers } \\
\text { before courses }\end{array}$ & $\begin{array}{l}\text { Students' answers } \\
\text { after courses }\end{array}$ \\
\hline SCE-1A & 8 & SCE-2A & 39 & 32 \\
\hline SCE-1C & 6 & SCE-2D & 20 & 16 \\
\hline SCE-1D & 7 & SCE-2H & 18 & 15 \\
\hline SCE-1E & 7 & SCE-2L & 37 & 34 \\
\hline SCE-1N & 10 & ESCE-2M & 16 & 17 \\
\hline CSS-1B & 14 & CSS-2B & 29 & 29 \\
\hline CSS-1F & 7 & CSS-2C & 14 & 13 \\
\hline CSS-1G & 6 & CSS-2D & 12 & 13 \\
\hline \multirow[t]{3}{*}{ Total } & 65 & CSS-2la & 29 & 35 \\
\hline & & CSS-2lb & 28 & 31 \\
\hline & & Total & 242 & 235 \\
\hline
\end{tabular}

\section{Results: the faculty's perspective}

\subsection{Didactic methodologies}

During the first semester where students were present directly in the classrooms, working in small groups was the most widely used teaching strategy ( $44.1 \%$ of the total hours), followed by individual work $(29.5 \%)$ and, finally, classic frontal exposition (26.4\%). In the second semester, with the need for working in distance through the forced mediation of software for e-meetings, the scenario was completely different: the most widely used teaching strategy was the classic frontal exposition (40.6\% of the total hours), followed by working in small groups (31.4\%) and individual work $(28 \%)$.

Between the first and the second semester - or better, between a situation of full presence and a situation of full epresence - the teaching strategies' preferences had changed. This shift towards a preference in using the classic frontal exposition in the second semester is due to the fact that teachers have been forced to change their plans on the go in a very short amount of time.

To understand the reasons about the previous answers better, it is noteworthy to see how teachers have reshaped and replanned their teaching in view of the need to carry out the workshops exclusively at a distance. Five out of 12 teachers replied that they had limited themselves to reducing the programme, 4 had made a change in teaching strategies, adapting them to the particularities of the situation, 2 had the need to propose alternative tools and, finally, 1 had not implemented any particularly relevant change.

Among the 12 teachers, only 6 stated that they had adapted their previous programmes to the new situation. The difficulties introduced by the digital tools not only to the set up and management of cooperative learning structures, but also to the communication processes made teachers to reduce the programme or adopt a less-interactive way of working. 


\section{Online computer science workshops for educators in higher education during Covid-19: challenges and opportunities of a forced distance learning \\ Pacetti, Soriani}

\subsection{Positive and critical aspects of the programmes}

When interviewed through two open-ended questions about what worked and what were the most critical elements, the professors reported, according to their point of view, that in general, the workshops were appreciated by the students for the competences acquired $(n=9)$ and for their usefulness $(n=8)$. Particularly relevant is the answer of a professor who lectured during the second semester and who, having managed to carry out the first lesson with students in attendance (pre-lockdown), reported how important it had been to have met the class in person, albeit once, for the success of the workshop (Fig. 2).

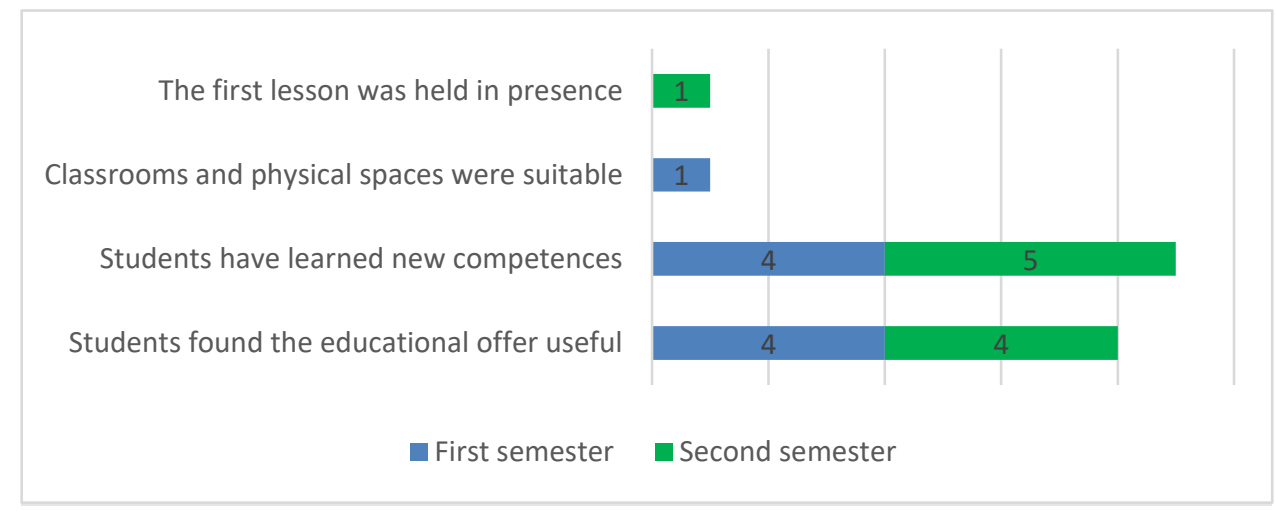

Fig. 2. Positive aspects related to the courses' proposals.

With respect to the critical issues that emerged, most of the teachers $(n=10)$ expressed that they did not encounter any particular difficulties. Three teachers of the FS expressed inadequacy of the classrooms and their tools, two teachers of the SS reported their difficulty in adapting the original proposal to distance learning, while one SS expressed his/her difficulty in dealing with students whose digital instruments were not always adequate (Fig. 3).

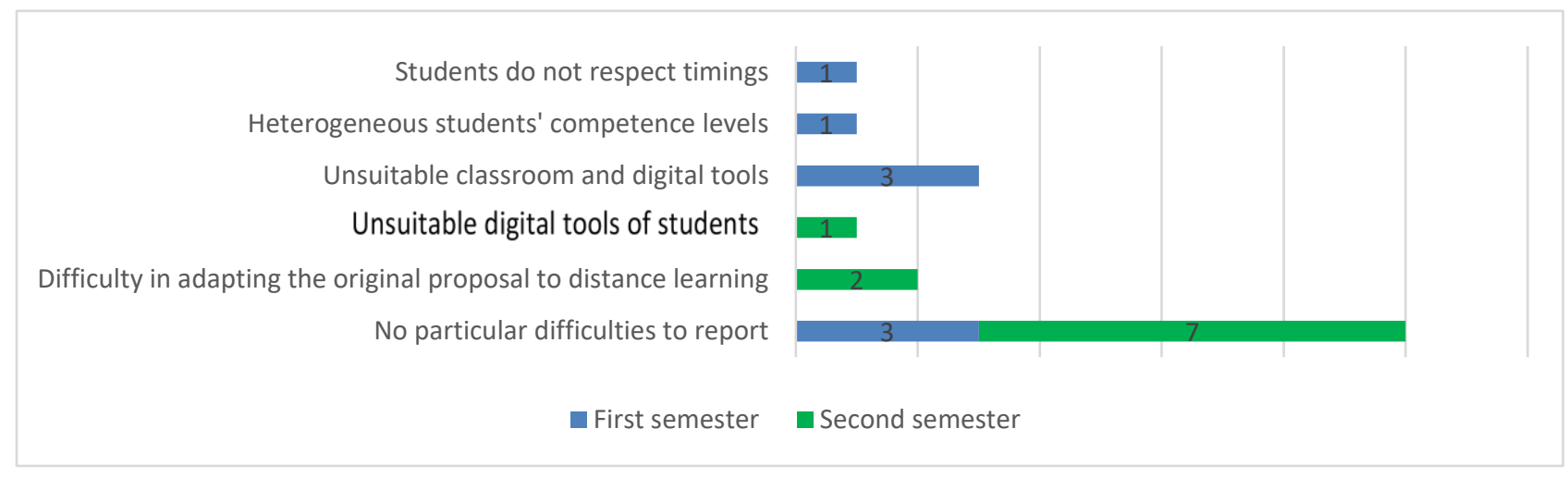

Fig 3. Critical aspects related to the courses' proposals.

\subsection{Positive and critical aspects of the emergency situation COVID-19}

The teachers of the second semester were asked, through a series of open questions, to express their perception of the aspects that they most appreciated and those that represented more difficulties than their distance learning experiences.

Among the elements that were most appreciated were a significant exchange and comparison with the students despite the digital medium $(n=3)$, the students' autonomy in carrying out the work $(n=2)$, being able to carry out the programme anyway $(n=2)$ and the possibility of sharing materials more easily $(n=1)$.

Difficulties that were reported included the disparity in terms of students' technological equipment $(n=3)$, time dilation caused by communication through an online meeting platform $(n=3)$, difficulty in implementing traditional teaching $(n=2)$, impossibility to propose the originally designed programme $(n=2)$, limitations of the platform and students' technical difficulties $(n=2)$ and the students' unavailability to install new software on their personal devices (n $=1$ ). 


\section{Online computer science workshops for educators in higher education during Covid-19: challenges and opportunities of a forced distance learning \\ Pacetti, Soriani}

\section{Results: the students' perspective}

\subsection{Perceptions about the programmes}

Students' perceptions about the effectiveness of the teacher's teaching strategies, the enjoyment of the programmes and the usefulness of the workshop proposal for the future educational profession were collected through some closed questions (on Likert scale 1-4). As can be seen in the graph overleaf, the workshops of the first and second semesters were, in general, appreciated both in terms of the effectiveness of the teaching strategies introduced by the teacher (FS = $3.20, \mathrm{SS}=3.40)$ and in terms of the proposal of the programmes $(\mathrm{FS}=3.17, \mathrm{SS}=3.39)$. The only element that marked a difference between the perceptions of FS and SS was the usefulness of the programme for the educational profession ( $\mathrm{FS}=2.88, \mathrm{SS}=3.27$ ). As can be observed in Fig. 4, the second semester's workshops were recognised as more useful for the educational profession.

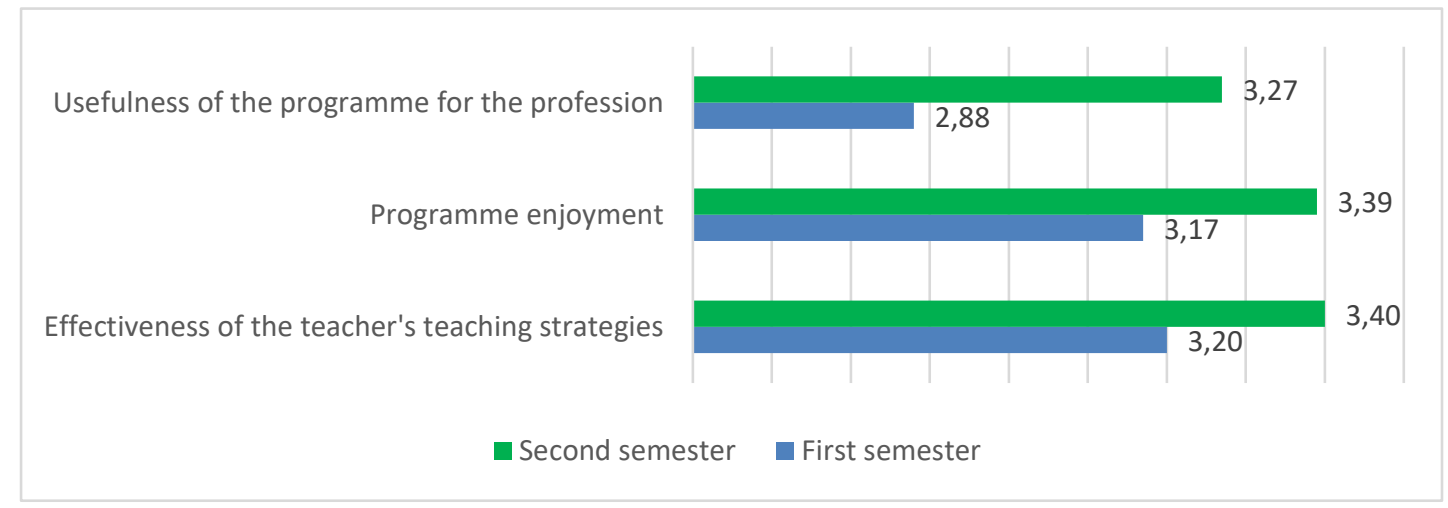

Figure 4. Students' perspectives about the aspects of the educational proposal. Likert scale values: 1 (low)-4 (high).

Motivations for these answers can be found in the open questions where students were asked to provide reasons about why they did answer in the way they did. We find primarily an increase in personal skills regarding technologies that was achieved through the practice of online use, secondly, the opportunity to see and try new techniques and new tools to be proposed in their working contexts and, finally, the variety of tools proposed by the teachers.

The fact that there is such an evident gap between the perceptions regarding the usefulness of the programme proposed by teachers for the educational profession among students in the first and second semesters is particularly relevant. Having experienced the necessity and usefulness of digital tools during such an unprecedented moment of need has undoubtedly highlighted how important digital skills are for the educational profession. In other words, the practical use of technologies (i.e. online conference tools, LCMS, tools for creating blogs, podcasts, videos) has evidently increased learners' (in this case, future educators) awareness regarding the importance of developing digital competences and the importance of planning educational activities not focused on the simple use of digital tools but on the real learners' needs.

\subsection{Perceptions about the programmes}

The students of the second semester were asked to answer some questions aimed at grasping their perceptions of distance learning. Fig. 5 shows their responses related to the presence of technical difficulties, other types of difficulties and the level of satisfaction with remote working methods. The questions were of the closed Likert scale type, in which students could express a low level by selecting 1, medium-low by selecting 2, medium-high by selecting 3 and high by selecting 4.

How satisfied are you with the distance-working mode used?

Have you encountered any other difficulties (communication with peers, attention threshold, etc.)?

Have you encountered technical difficulties (connection, use of the platform, etc.)?

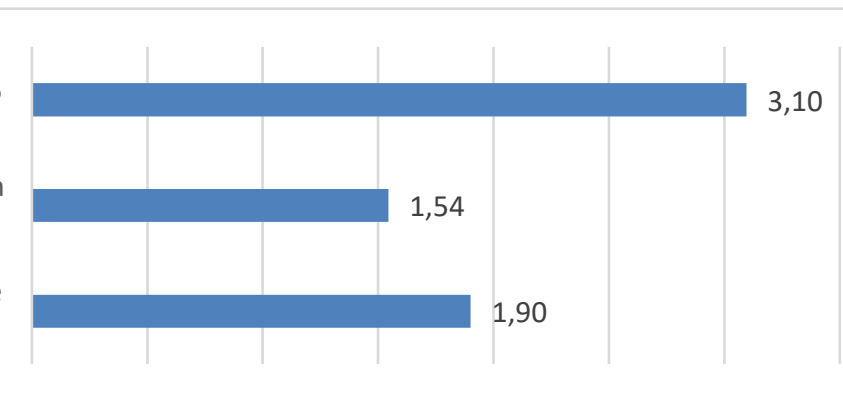

Figure 5. Students' perspectives related to the second semester's remote workshop proposal. Likert scale values: 1 (low)-4 (high). 


\section{Online computer science workshops for educators in higher education during Covid-19: challenges and opportunities of a forced distance learning \\ Pacetti, Soriani}

When asked 'Have you encountered technical difficulties (connection, use of the platform, etc.)', the average Likert value was 1.90 , which shows that no particular technical difficulties had been encountered. In this regard, in the open question on the types of technical difficulties, $20 \%$ of students reported the poor quality of their connections, $4.7 \%$ reported problems of access to programmes and 3.4\% reported the slowness of their PC. Only one student said that she had difficulties in following the lessons because she had to use her smartphone as she did not have a PC.

With regard to other types of difficulties, the average Likert value was 1.54, and this can be interpreted in terms of a low presence of other difficulties compared to the technical ones among the students. The only noteworthy element expressed in the open-ended questions was the one related to the difficulty in maintaining attention for a long time during the online lessons $(8.5 \%)$.

With regard to the question 'How satisfied are you with the remote working methods used?', the answers were at a medium-high level of satisfaction (Likert $=3.10$ ). The most appreciated aspects were the possibility of working from home without transport problems, laboratory $(9.8 \%)$, collaboration among peers $(3.8 \%)$, kindness of the teacher $(3.4 \%)$ and the teaching strategies used by him/her (3\%). The students also expressed, although in smaller numbers, some elements to be taken into consideration for an improvement of the workshop proposal at a distance. The two most relevant observations were the need to design ways of working that are more appropriate to distance working (1.7\%) and a greater attention to time $(1.3 \%)$.

\section{Conclusions}

The Covid-19 emergency deeply disrupted the workshop teaching dynamics also. Prior to the Covid emergency, the personnel of the 'Computer Science Lab-based course' for Educators (ESC and ESI) were deeply rooted in classroom teaching; yet, after lockdown, measures were necessary that inevitably led teachers to transform and rethink their programmes and methods of exposure to the classroom group, so that they could be delivered at a distance through video lectures.

This has led, as can be seen from teachers' responses, to an increase, compared to the first semester, in the use of more traditional forms of teaching related to the receptive/transmitting architecture of education (Bonaiuti, 2014). The motivation for this trend can be found in the lack of programme design and planning, fundamental for a distance learning course (Hodges et al., 2020), and in particular, it causes the following:

1. Time management not always effective: Teachers accustomed to working in the classroom according to a workshop model expressed that during the time reserved for explanation and the time allotted for individual or group work $-\mathrm{a}$ model that works when students are present because of the possibility of having a constant flow of non-verbal feedback from the class - they have applied the same model, maintaining the same timing that they would have kept when their students were present. Unfortunately, the interaction at a distance provides much more extended times for any action that goes beyond the simple exposition of concepts and this has led to an imbalance in timing.

2. Difficulty in adapting the proposal in the presence of long-distance learning: Some teachers declared difficulty (if not the impossibility) in adapting the programme from when students are present in the workshop to a remote mode. This caused replacement of some experiences (e.g. such as visiting particular places or some group work activities with the students present) with more expositive and narrative moments.

3. Ease and sense of security: Implementing group work or cooperative learning structures through a virtual environment represents a very complex and cumbersome task for a teacher who finds himself forced, in a very short time, to readjust his programme. In this sense, the frontal lesson or transmission mode is undoubtedly easier to manage.

On the other hand, the balance of the experience is largely positive thanks to the didactic proposals of teachers and lecturers who were already strongly focused on doing and working in groups and on peer comparison. These have not undergone major readjustments and have worked nimbly even at a distance, testifying to the fact that good workshop design is able to provide an adequate response to this type of situation and teachers have confirmed the importance of experiential teaching able to actively involve students.

In conclusion, it can be said that the experience of workshop teaching at a distance has worked and the teachers were able to guarantee a service (the coverage of the teaching), even in a complex and delicate moment like the one just experienced. The situation also allowed students to effectively acquire digital skills remotely.

With regard to the aspects to be improved that emerged from the survey, the following three areas of possible intervention can be identified:

- Technical aspects:

- Attention must be paid to the students' hardware and software equipment. Being able to propose open-source software, multiplatform, easily installable on any operating system or usable through the web, is undoubtedly important to include each student and allow them to participate in the workshop.

- Efficiency of the communication platform and greater mastery of the same by the actors involved. For truly effective workshop teaching, it is necessary that the communication platform is really usable and that it puts 


\section{Online computer science workshops for educators in higher education during Covid-19: challenges and opportunities of a forced distance learning \\ Pacetti, Soriani}

teachers and students in a position not to have to worry about the technical aspects. It is also necessary that the actors involved are trained on how to access these platforms and that they know how to use the basic functionalities and also how to organise private rooms and collaborative work in small groups.

- Relational aspects:

- Peer communication. In a situation of distance learning, the dimension of relationship and comparison, even in informal moments, between peers is certainly missing. This is an aspect not to be underestimated because a good social climate is a source of motivation, greater learning and greater satisfaction (Soriani, 2019). However, technologies are able to influence the relational exchanges in an important way, and moments of confrontation, dialogue and exchange with respect to the issues addressed in class become an important element able to deeply change the learning experience.

- Teacher-student communication. The immediacy and the possibility of interacting in times unrelated to the lessons are undoubtedly an aspect to be enhanced. The distance laboratory formula allows you to take advantage of the relational possibilities that technologies offer. Knowing how to establish a fertile communicative exchange and a source of constant comparison is certainly an important aspect to be taken into account if you want to create a 'third space' where you can continue your professional growth and reflection on what you faced in class.

- Didactic aspects:

- Threshold of attention and balance of teaching strategies. One of the critical elements that emerged most strongly from the students' voices is the difficulty in maintaining a threshold of attention during the distance lesson sessions. Therefore, it is advisable to balance moments of exposure with more interactive sessions such as question-answer, online quizzes or small group work.

It seems necessary to reflect on the importance of a workshop proposal that stimulates the digital competences of future educators, starting from the concept of competence. In this sense, there is a need for workshop experiences that propose training paths able to stimulate future educators to effectively and adequately orchestrate their knowledge and skills regarding technologies in order for them to be able to apply them in real and professional contexts in which they will operate, contexts where at the centre of everything one will inevitably find the educational needs of the people with whom they will operate and relate.

Knowing how to comprehend these needs and being able to design educational proposals, also concerning the use of digital tools, becomes a fundamental competence. The risk, talking about paths of education to technology, is in fact to propose pre-packaged activities (e.g. the use of applications such as Scratch to stimulate coding skills or small devices such as Bee-Bot to develop computational thinking) without, however, making a reflection on the meaning of the proposal or without taking into account the real needs of its users.

At this point, we would like to ask a question: the workshop experiences that were the subject of the research are strongly linked, due to the disciplinary object (they were computer labs for education), to the world of ICT and digital skills. In this sense, we can affirm that these workshops have increased the reflexivity of students because 'The media also produce reflexive professionalism, possible insights and new sociality and participation' (Rossi, 2019, p. 56). It would be interesting to be able to comprehend how much the success of the experience is determined by the theme of teaching and how other workshops of other disciplines have conducted distance learning.

Finally, it is necessary to make a last reflection on the possibility of rethinking the meaning of distance learning in the face of what we have just learned from the experience. Designing the different proposals in a systematic way, in collaboration with the other teachers working on the different programmes, is undoubtedly the first action that would be useful to improve the proposal. Another element to consider is to implement blended teaching methods that enhance and hybridise moments of relationship with the students present (if possible, of course) or through 'third' spaces, with practical moments of reflection around the experiences. In Schön's words, 'We must not only become capable of transforming our institutions in response to changing situations and demands, we must invent and develop institutions that are "learning systems", that is, systems capable of achieving their continuous transformation' (Schön, 1999, p. 49).

\section{Authors' contributions}

This article has been developed jointly by the authors. Elena Pacetti wrote the sections 1.1, 1.3, 2.1 and 2.2. Alessandro Soriani wrote the sections 1.2, 2.3, 2.4, 3 and 4. Section 5 was written jointly.

\section{References}

Bonaiuti, G. (2014). Le strategie didattiche ( $7^{\circ}$ ristampa). Roma, IT: Carrocci.

Bruschi, B. (2020). Università dopo l'emergenza: quali opportunità? Il caso dell’Università di Torino. Scuola democratica, 11(3), 583-590. 


\section{Online computer science workshops for educators in higher education during Covid-19: challenges and opportunities of a forced distance learning \\ Pacetti, Soriani}

Calvani, A., Fini, A., \& Ranieri, M. (2010). La competenza digitale nella scuola. Modelli, strumenti, ricerche. Giornale Italiano Della Ricerca Educativa, 5, 9-21.

Carrettero Gomez, S., Vuorikari, R., \& Punie, Y. (2017). DigComp 2.1: The Digital Competence Framework for Citizens with eight proficiency levels and examples of use. Publications Office of the European Union. Retrieved from: http://publications.jrc.ec.europa.eu/repository/bitstream/JRC106281/web-digcomp2.1pdf_(online).pdf

Di Palma, D., \& Belfiore, P. (2020). La trasformazione didattica universitaria ai tempi del Covid-19: un'opportunità di innovazione?. FORMAZIONE \& INSEGNAMENTO. Rivista internazionale di Scienze dell'educazione e della formazione, 18(1), 281-293.

European Commission (2003). The role of the Universities in the Europe of knowledge. Retrieved from: http://eurlex.europa.eu/legal-content/EN/TXT/?uri=uriserv:c11067

Ferrari, A. (2013). DIGCOMP: A Framework for Developing and Understanding Digital Competence in Europe. (Y. Punie \& B. Brecko, Eds.). Publications Office of the European Union. Retrieved from: http://publications.jrc.ec.europa.eu/repository/handle/JRC83167

Giovannella C. (2020). Effect Induced by the Covid-19 Pandemic on Students' Perception About Technologies and Distance Learning. Ludic, Co-design and Tools Supporting Smart Learning Ecosystems and Smart Education: Proceedings of the 5th International Conference on Smart Learning Ecosystems and Regional Development, 197, 105-116. Retrieved from: https://doi.org/10.1007/978-981-15-7383-5_9

Harrison, T. (2020). How distance education students perceive the impact of teaching videos on their learning. Open Learning: The Journal of Open, Distance and e-Learning, 35(3), 260-276.

Hodges, C., Moore, S., Lockee, B., Trust, T., \& Bond, A. (2020). The difference between emergency remote teaching and online learning. Educause Review, 27 March. Retrieved from: https://er.educause.edu/articles/2020/3/thedifference-between-emergency-remote-teaching-and-online-learning

Honebein, P. C. (1996). Seven goals for the design of constructivist learning environments. In Wilson, Brent. G. (Ed.). (1996), Constructivist learning environments: case studies in instructional design (11-24). Educational Technology Publications Englewood Cliffs, New Jersey .

Iori, V. (2018). Le professioni educative e la formazione pedagogica. In V. Iori (ed.), Educatori e pedagogisti. Senso dell'agire educativo e riconoscimento professionale (15-38). Milano: FrancoAngeli.

Joint Quality Initiative informal group (2002). Towards shared descriptors for Bachelors and Masters. Retrieved from: http://www.ehea.info/media.ehea.info/file/Quality_Amsterdam_March_2002/01/2/020312-13_Quality3 576012.pdf

Luppi, E., Freo, M., Ricci, A., \& Gueglio, N. (2020). L'innovazione della didattica all'Università di Bologna durante la pandemia: un percorso basato sulla ricerca valutativa. Lifelong Lifewide Learning, 16(36), 44-57. Retrieved from: http://www.edaforum.it/ojs/index.php/LLL/article/view/557

Means, B., Bakia, M., Murphy, R. (2014). Learning Online: What Research Tells Us about Whether, When and How. New York: Routledge.

Oggionni, F., \& Palmieri, C. (2019). Il tirocinio universitario per la figura professionale dell'educatore sociopedagogico. L'esperienza formativa del Corso di Laurea in Scienze dell'educazione dell'Università degli Studi di Milano-Bicocca. Annali online della Didattica e della Formazione Docente, 11(18), 207-220.

Pacetti, E. (2017). Active learning and placement in pre-service teacher training for inclusion. In Saqipi B., Vogrinc J. (eds.), The prospects of reforming teacher education (203-220). Prishtinë: Shtëpia Botuese Libri Shkollor.

Perla, L., Felisatti, E., Grion, V., Agrati, L., Gallelli, R., Vinci, V., Amati, I., \& Bonelli, R. (2020). Oltre 1'era Covid-19: dall'emergenza alle prospettive di sviluppo professionale. Excellence And Innovation In Learning And Teaching Open Access, 5(2). Retrieved from: https://ojs.francoangeli.it/_ojs/index.php/exioa/article/view/10802

Redecker, C. \& Punie, Y. (2017). European Framework for the Digital Competence of Educators. DigCompEdu. Publications Office of the European Union. Retrieved from: https://ec.europa.eu/jrc/en/publication/eur-scientificand-technical-research-reports/european-framework-digital-competence-educators-digcompedu

Riedling, A. M. (2020). Distance education: The technology-what you need to know to succeed, an overview. $A A C E$ Review (Formerly AACE Journal), 18(1), 8-13.

Rosati, A., \& De Santis, M. (2020). Identità professionale e scelte formative. Form@re - Open Journal Per La Formazione in Rete, 20(2), 117-132.

Rossi, P.G. (2019). La formazione mediale dell'educatore sociale. In Bruni, F., Garavaglia, A., Petti, L. (eds), Media Education in Italia. Oggetti e ambiti della formazione (55-66). Milano: FrancoAngeli.

Rychen, D.S., Salganik, L.K., (2003). Key Competencies for a Successful Life and a Well- Functioning Society. Germany: Hogrefe \& Huber.

Schön, D. (1999). Il professionista riflessivo. Per una nuova epistemologia della pratica professionale. Bari: Dedalo.

Soriani, A. (2019). Sottobanco. L'influenza delle tecnologie sul clima di classe. Milano: FrancoAngeli.

Vuorikari, R., Punie, Y., Carrettero Gomez, S., \& Van Den Brande, G. (2016). DigComp 2.0: The Digital Competence Framework for Citizens. Update Phase 1: the Conceptual Reference Model. Publications Office of the European Union. Retrieved from: https://ec.europa.eu/jrc/en/publication/eur-scientific-and-technical-researchreports/digcomp-20-digital-competence-framework-citizens-update-phase-1-conceptual-reference-model 
Online computer science workshops for educators in higher education during Covid-19: challenges and opportunities of a forced distance learning

Pacetti, Soriani

Whittle, M., Rampton, J. (2020). Towards a 2030 Vision on the Future of Universities in Europe. Luxembourg, BE: Publications Office of the European Union. Retrieved from: https://op.europa.eu/en/publication-detail//publication/a3cde934-12a0-11eb-9a54-01aa75ed71a1

Williamson, B., Eynon, R., \& Potter, J. (2020). Pandemic politics, pedagogies and practices: digital technologies and distance education during the coronavirus emergency. Learning, Media and Technology, 45:2, 107-114. Retrieved from: https://www.tandfonline.com/doi/full/10.1080/17439884.2020.1761641 